\title{
OBITUARIES
}

\section{Prof. F. J. Cole, F.R.S.}

Francis Josere Cole was born at Clapham in 1872 , and by his death on January 27, a week before his eighty-seventh birthday, British zoology lost an outstanding scholar. He was educated at Sir Walter St. Johns School, Battersea, where the only science subject he studied was physics. Reading Darwin's "Vegetable Moulds and Earthworms" in his teens inspired him to keep and study these creatures, and his first three publications were notes on his observations. He also started buying books, and E. B. Wilson's classical memoir on the development of the earthworm made a deep impression on him by the accuracy of description, careful illustration and extensive bibliography.

In 1892 he was assistant to Prof. J. Cossar Ewart in Edinburgh, and his experience while there played a significant part in shaping his subsequent career. $\mathrm{He}$ collaborated with Ewart in a paper on the cranial nerves of elasmobranchs, the forerunner of a series of publications on the cranial nerves of fishes which firmly established his reputation as an able comparative anatomist and were recognized by the award of the Rolleston Prize by Oxford in 1902. These researches contributed to the establishment of the now generally accepted 'component theory of the nervous system' and they brought to his notice the works of the old masters of anatomy.

In 1895 Cole went to Liverpool as lecturer under Prof. W. Herdman, continued his line of research, and with James Johnstone produced "Pleuronectes", which still remains the longest of the well-known Liverpool Marine Biological Committee (L.M.B.C.) momoirs and shows clearly his noteworthy dexterity in dissecting and illustrating. A proposed momoir on the sea lamprey, Myxine, became expanded into a detailed monograph and brought him into contact with Prof. G. B. Howes, whom he regarded as the most learned zoologist he had ever met and the main person to substantiate his interest in bibliography. The first part appeared in the Transactions of the Royal Society of Edinburgh in 1905 and was followed by five further parts which set a, standard of meticulous accuracy that has not often been reached. As the result of the earlier parts of this and his other work, he received the Neill Gold Medal of the Society. While at Liverpool, arrangements were made for him to keep terms at Jesus College, Oxford, where he obtained his B.Sc., and later the University conferred on him the D.Se.

Cole went to what was then University College, Reading, in 1905 to found a Department of Zoology, and the following year was appointed to the chair, which he held until his retirement in 1939 . He threw himself whole-heartedly into the task of building up the Department and, indeed, by his example and wise counsel played an appreciable part in the development of the young University. One of his first objects was to set up a museum, which from the beginning contained deliberately chosen specimens most carefully prepared and mounted and catalogued and written up in several volumes. It formed an outstanding and widely admired feature of the Department and represented an enormous amount of hard work and thoughtful planning. He retained a connexion with Liverpool, for he continued to take his senior students to Port Erin Biological Station, and several of his students contributed important memoirs to the Liverpool Marine Biological Committee series. In 1926 he was elected a Fellow of the Royal Society.

His inquiring mind and interest in things historical turned Cole's attention to the medieval architecture of the churches in the countryside around Reading and to the writing of an interesting analysis of the church of St. Mary, Cholsey. He now devoted more attention to the bibliography and history of comparative anatomy and published a number of contributions on these subjects, including, in 1944, an important book on the "History of Comparative Anatomy : from Aristotle to the Eighteenth Century". Always interested in books, he gathered a most remarkable and valuable library in his own field, which contains a number of very rare early works and is exceptionally complete. Indeed, the museurn of his Department and his library were his muchloved and cared-for 'scientific children'. His first contribution to Nature was in 1895 , and then there was a long gap; but readers will recall the series of articles and reviews since his retirement that gave some indication of his wide knowledge and sound judgment. His particular period was the Dutch microscopists of the seventeenth century, especially Leeuwenhoek. Just before and during this time he played a much appreciated part in the development of the newly instituted subject of history and philosophy of science in the University of London. For twenty-five years he served as external examiner and for a year less as member of the Board of Studies.

He was a tall, impressive man who would have appeared somewhat forbidding if this were not contradicted by the twinkle in his eyes. Gifted with a most retentive memory and, in addition to his zoological and bibliographical lore, a good knowledge of classical music and of the old masters of the Dutch and Flemish Schools, his conversation was well worth while, particularly as it was spiced with a quiet, dry humour. His teaching was always thorough and inspiring, and his students retained a great respect and affection for him. He will retain a warm place in their memories and in those of his colleagues. He is survived by a wife and a son, to whom we offer our sincere sympathy. Chas. H. O'DONOGHUE

\section{Dr. Karl Jordan, F.R.S.}

$I_{T}$ is not given to many men to cover a span of seventy years with worth-while contributions to any science. Karl Jordan's first published work was an account of the lepidopterous fauna of Göttingen, a university dissertation submitted on his doctorate. In the next three years he gave rein to his childhood passion for beetles by publishing numerous supplemonts to the list of beetles of Hildesheim, his home town, near which he was born on December 7, 1861 . The seventh son of a small farmer, Heinrich Ernst Karl Jordan had many duties to perform, besides going to school; but it was while going about these tasks that he had become interested in insects. He 
often related that the Carabidae in particular fas. cinated him. It was not just because they varied so much in colour, nor was it the mechanism of this variation that attracted him; the great question was 'why' did they vary. It is this theme that runs like a thread through all his writings.

At Göttingen he had been awarded the coveted Summa cum Laude in botany and zoology and afterwards obtained a diploma in teaching - a fact which his own daughters learnt later to appreciate. A year of voluntary military training was followed by appointments in the grammar school at Münden and at the School of Agriculture at Hildesheim. In 1891 he was able at last to marry the girl who had waited for him since both were in their 'teens; their marriage could not have been happier.

At the age of thirty-two, already with wide experience behind him, Jordan seemed set for a distinguished academic career. It was then that chance brought him in contact with Ernst Hartert, who had just been appointed by Walter (later Lord) Rothschild to be director of the Zoological Museum which he had formed at Tring - in two small cottages. Jordan's first task on arrival at Tring was to reduce to order the immense but chaotic collection of beetles (the Lepidoptera were already in better shape) stored in various parts of Tring, without proper working conditions or even a microscope. It was just what he wanted, a marvellous enforced exercise in the study of geographical variation, and any odd corner served as a bench. However, it soon became apparent that not even his devoted labours, carried far into the night, could cope with both the Coleoptera and the Lepidoptera at Tring, and before long the collection of the former was abandoned, except the Anthribiidae, a group of weevil-like beetles the complexity of which never ceased to fascinate Jordan, and on which alone he published more than eighty papers.

Meanwhile, Walter Rothschild, who was deeply involved in a systematic revision of the swallow-tai butterflies of the Oriental Region, enlisted Jordan's help. In a long introductory passage, Jordan (1895) proved himself some fifty years ahead of his time : he clearly appreciated the importance of populations as basic taxons, distinguished between individual, environmental and geographical variation, according the last firmly and precisely subspecific rank and applying a trinomial system of nomenclature exclusively to it. Here, too, he recognized the importance of the type system. During the next ten or twelve years other similar monographs appeared, on the hawk-moths, on the American swallow-tails, on the genus Charaxes, on certain families of emperor moths. These impressive monographs were built soundly on the most painstaking attention to detail, whether concerned with morphological minutiæ, distribution or bibliography; all the essential evidence available at the time, and a very great deal of entirely new and original matter, were welded together concisely in masterly fashion. However, this systematic work was by no means an end in itself.

Simultaneously, Jordan was publishing on pure morphology, on sense organs, on mimicry among butterflies and its significance for evolution, on geographical variation in relation to evolution, on 'mechanical' selection, and so on. 'Throughout his writings there is the constant theme that experimental biology and systematics are interdependent; neither can be complete, or even wholly dependable, without the other. The study of systematics was to him a means for proving the truth of evolution, and, as another writer has said, he "exerted an influence on the development of systematics and on evolutionary thought that cannot be over-estimated". It is quite possible, however, that his unpublished influence was equally great, for no one could have been more generous than Jordan in the inspiring help he gave so freely to his innumerable correspondents in all parts of the world.

At the age of seventy-four, Jordan made his first really ambitious collecting expedition, to South West Africa. When well over eighty, he remarked that it was time he started on his catalogue of fleas, a task he felt he owed to Charles Rothschild. The story of their fruitful co-operation has been told elsewhere; it was left to Miriam Rothschild, one of his most ardent disciples and admirers, to undertake this task, with the help of the Trustees of the British Museum. On his ninety-fourth birthday the Royal Entomological Society of London published a special volume in his honour, an event unique in its history and more significant an indication of the esteem in which he was held than anything these few words can convey. My own lasting impression is one of effervescent enthusiasm, intense interest in discovery and in the future, of the unexpected wit with which he would enliven a dull discussion, of his unfailing, unstinted help and kindliness, and of the fruitfulness of his long and happy life. He died on January 12, in his ninety-eighth year.

N. D. RILEY

\section{Dr. J. Travis Jenkins, O.B.E.}

Dr. James Travis Jenkins died on January 12, at his home, Henbant Hall, Capel Dewi, Llandyssul, Cardiganshire. Born in 1876, the son of a schoolmaster, he attended school first at Pontardawe, Glamorgan, and then at the Merchant Venturers' School, Bristol. Afterwards he attended the University Colleges of Aberystwyth and Cardiff, and in 1897 graduated B.Sc. of the University of Wales. Only three years afterwards (1900) he was awarded the doctor of science degree of the University of Wales for a thesis on the anatomy of the oyster. His early preoccupation with marine zoology, and particularly with its economic aspects, was also shown in his work at Kiel, where a year or two later he was awarded a doctorate of philosophy.

In 1904 Jenkins was appointed superintendent of the Lancashire and Western Sea Fisheries Joint Committee, and this post he held until his retirement in 1946, except for a short period during 1908-10, when he was seconded to the Bengal Government to investigate and organize the fisheries of the Bay of Bengal. On Indian fishes and fisheries he published a number of papers, some under the seal of the Bengal Government, others in the Records of the Indian Museum. He retained his interest in the subject in later years, and even so late as 1938 an article by him on "The Fisheries of Bengal-Can they be Developed and Improved?" appeared in Current Science.

As superintendent of the Lancashire and Western Sea Fisheries Joint Committee, Jenkins was responsible for a long series of quarterly reports dealing with the mussel, cockle and other fisheries of the Com. mittee's district and with the various laws and regulations relating to these. In addition to his scientific qualifications, he was admitted a barrister of Gray's Inn in 1910. He acted for many years as honorary secretary of the Association of Sea Fisheries Committees of England and Wales. His work for 